\title{
ソフト界面の分子膜の精密構造解析 II : X 線反射率法 Precise Structural Analysis of Molecular Layer at Soft Interface II : X-ray Reflectometry
}

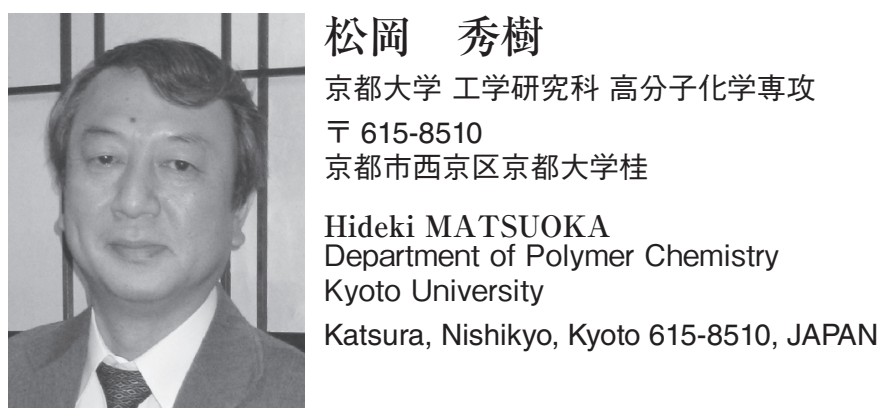

論文要旨：X 線反射率法は, 表面・界面のナノ構造を非破壊かつ高精度で解析できる非常に有用な手法で ある。その原理を簡単に解説した後, イオン性両親媒性高分子が水面上で形成する単分子膜のナノ構造, と くに水面下に形成される高分子電解質ブラシのナノ構造とその転移に応用した例を紹介する。強酸性ブラシ と弱酸性ブラシでは, その形成機構が異なり, 添加塩に対する応答性も異なる様子などを定量的に知ること ができる。

\begin{abstract}
X-ray reflectometry is very useful technique for in situ nanostructure analysis of surfaces and interfaces with very high accuracy. Its principle and application to monolayer of ionic amphiphilic diblock copolymer at the air/water interface are described. Especially, information on the nanostructure and its transition of polyelectrolyte brush under the water could be quantitatively obtained. As a result, the differences of brush formation mechanism and response to added salt were clarified.
\end{abstract}

Key words: X-ray reflectometry, polymer monolayer, polyelectrolyte brush, air/water interface

\section{1 はじめに}

試料表面・界面にX $\mathrm{X}$ 線を入射し, 反射されたX 線の 強度を測定する X 線反射率 (X-ray Reflectometry, XR) は, 表面・界面のナノ構造を非破壊かつ高精度で測定す る手法であり，入射光に中性子を用いる中性子反射率法 (Neutron Reflectometry, NR) と並んで, 表面·界面研 究に必須の手段である。1931 年に Kiessig ${ }^{1)}$ が, Ni の薄 膜に関して測定を行い，干渉縞を観測したのが最初と言 われているが, 近年は, 多層膜や高分子薄膜, 単分子膜, Langmuir-Blodgett（LB）膜などの「ソフト」な系に対 しても幅広く応用され, その膜厚や表面・界面粗さ, 各 層（膜）内の電子密度の評価などが行われている ${ }^{2-5)}$ 。

反射率法の長所の一つは, 固体基板上の薄膜 - 分子膜 のみならず，液面および水面の単分子膜等をそのまま

連絡者：松岡 秀樹

E-mail : matsuoka@star.polym.kyoto-u.ac.jp in situにて測定可能であることである。水面の XR 測定 は, 1985 年の Pershan らによる報告が最初と言われ， 水面上の表面張力波の検出に成功している ${ }^{6)}$ 。さらには, 近年, 放射光 $X$ 線を用いての, 液液界面の測定例も報 告されている ${ }^{7,8)}$ 。

1995 年に, 当時としては本邦初の水面上の単分子膜が 測定可能な, 実験室レベルの試料水平型 $\mathrm{X}$ 線反射率装置 を導入し，水面高分子単分子膜の研究を開始した ${ }^{9,10)}$ 。 その後, イオン性両親媒性ジブロックコポリマー単分子 膜のナノ構造研究へと発展し, とくに, 単分子膜中の高 分子電解質ブラシ部分のナノ構造とその転移現象を発 見, 解明し, 高分子電解質ブラシの形成機構の詳細, そ してそれが, 強イオン性, 弱イオン性のブラシなどで異 なることを見いだしている ${ }^{11-13)}$ 。本稿では, これら最 近の成果をまとめ, XR 法のソフト界面のナノ構造解析 への有用性を紹介したい。 


\section{$2 \mathrm{X}$ 線反射率法の原理}

XRには，波長の揃った単色光を用いて，反射角度の 関数として測定する角度分散法と, 白色 X 線を用いて, 一定角度で反射された X 線の波長と強度を測定するエ ネルギー分散法があるが, 本稿では, 前者のみ紹介する。 また，角度分散法においても，さらに，入射角度と反射 角度が対称な条件で測定する specular（鏡面反射）測定 と, 非対称な off-specular（非鏡面反射） 測定 ${ }^{2-5}$ があ るが，本稿では，表面（界面）に垂直方向のナノ構造情 報が得られる specular 測定の例のみ紹介する。

Fig. 1 は，表面での X 線の反射と反射率曲線の模式図 である。実際の測定では，入射・反射角度は，0５度 程度と極めて浅いが，この図ではわかりやすくするため 角度を誇張して描いてある。X 線の屈折率は, 大抵の物 質に対して，1より小さいため, 臨界角 $\theta c$ が存在し, 入射角が $\theta c$ 以下では， $X$ 線は全反射され，反射率 $\mathrm{R} （=$ 反射強度と入射強度の比）は，1 となる。入射・㴬角 度を徐々に大きくしていき, $\theta \mathrm{c}$ を越えると, 反射率 $\mathrm{R}$ は, 1 から急激に減少していく。この時，表面が完全に平滑

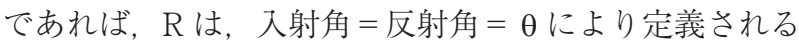
散乱べクトル qのー4乗に比例して減衰することになる。 $\mathrm{q}=4 \pi \sin (\theta) / \lambda$ であり, ここで $\lambda$ は，X線の波長であ る.表面に粗さが存在すれば，反射しにくくなるため， より急激に減衰することになる。すなわち，減衰具合よ り，表面粗さに関する情報を得ることができる。

基板上の薄膜の場合，薄膜表面と薄膜／基盤の二つの 界面が存在し，X線はこれら両界面で反射される。Fig. 2 に示したように, この時, 結晶解析における Bragg の

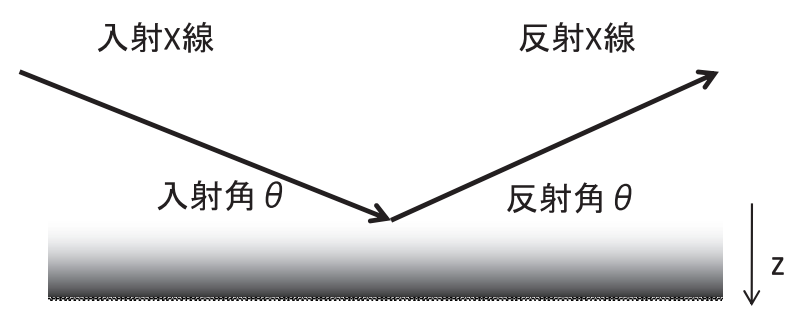

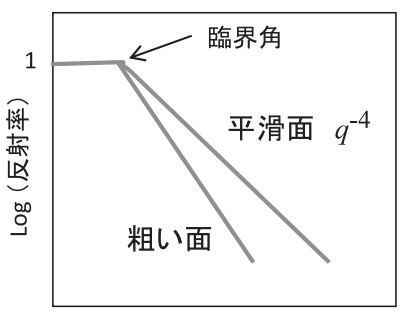

Log q（散乱ベクトル）

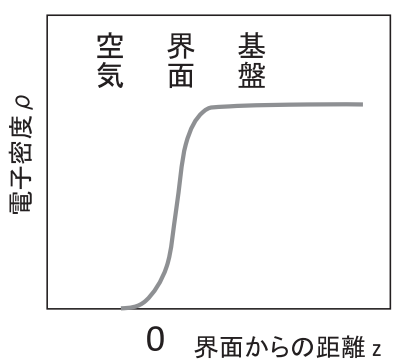

Fig. 1 （上）表面からのX 線の鏡面反射, （左下）反射率プ ロファイルの例。（右下）プロファイルから求められ る界面に垂直方向の電子密度プロファイルの例。
関係式と同様な原理で，表面で反射された X 線と界面 で反射された X 線が強め合う角度, 弱め合う角度があ ることになる。よって，反射率曲線には，Fig. 2 のよう な極大・極小が現れることになる。この縞模様は Kiessig フリンジと呼ばれる。その位置は, 膜厚に依存し, 明瞭さは, 表面・界面の粗さ, 各層の電子密度差を反映 する。

得られたプロファイルは, モデルを仮定して計算した 反射率曲線でフィッティングすることによって解析す る。この時の理論散乱曲線は, Parrattの理論 ${ }^{14)}$ により 計算されることが多い。実際には, Murex ${ }^{15)}$ やParratt $32^{16)}$ などのフリーソフトが良く用いられる。詳細は, 文献等を参照されたい。Fig. 3 は, 基板上の高分子薄膜 を想定し,（a）膜厚の影響，（b）高分子薄膜の電子密度, （c）薄膜表面の粗さ，（d）薄膜／基板界面の粗さ，をパ ラメータとして，XR曲線を計算したものである。フリ ンジの位置が膜厚に依存すること, 基板と薄膜の密度差 が大きいほど，明瞭なフリンジが現れること，表面・界 面の粗さが増大するとフリンジが不明瞭になるととも に, 減衰が速くなることなどが分かる。さらに, 表面粗 さと界面粗さが与える影響は異なり，この両者が区別で きることも分かる。

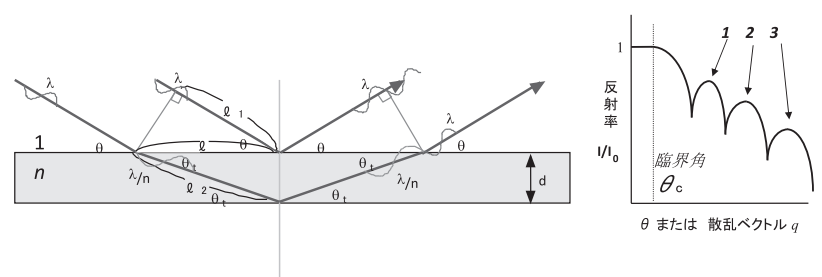

Fig. 2 (左) 薄膜からの X 線の反射, (右) 薄膜からの反射 率プロファイルの例。

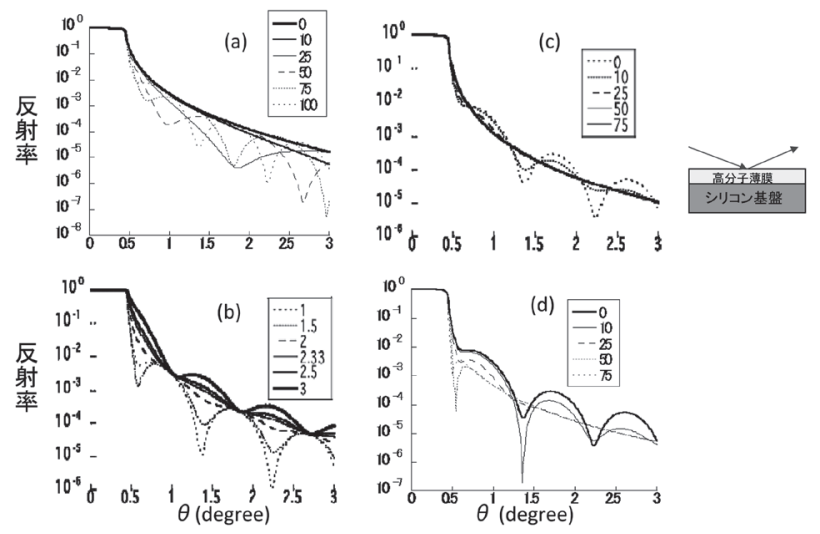

Fig. 3 シリコン基板（密度 $2.33 \mathrm{~g} / \mathrm{cm}^{3}$ ) 上の薄膜からの反 射率曲線のシミュレーション。(a)膜厚変化(単位 $\mathrm{A}$ ), （b）薄膜の密度変化 (単位 $\mathrm{g} / \mathrm{cm}^{3}$ ), （c）薄膜表面粗 さの影響（単位 $\AA$ ), （d）薄膜／基板界面粗さの影響 (単位 $\AA$ )。 


\section{$3 \mathrm{X}$ 線反射率装置}

Fig. 4 は, 当研究室のXR 装置の写真である。（株） リガクの RINT-TTR という試料水平型の回折計を改造 して反射率計としたものである。いわゆる「万歳ゴニオ」 であり, 光源と検出器を試料部を中心に回転させること ができ，試料を動かす必要はない。Ge 単結晶のチャン ネルカットモノクロメータが, 回転対陰極からの X 線 を，平行で単色の $\mathrm{CuK} \alpha_{1}$ 線（波長：1.5406 ̊）にして いる。試料部分は, USI 社（福岡）特注の LB トラフで あり，水面単分子膜を調製できるとともに，表面圧や一 分子当たりの専有面積を変化させながら測定可能となっ ている。なお，水面測定には振動が大敵なため，トラフ 部分は，磁気浮上式の除振台上に設置するなど，最大限 の配慮を行っている。ビームサイズは， $7 \mathrm{~mm}$ 程度 $\times 50$ $\mu \mathrm{m}$ とかなり細くし，分解能を向上させているが，それ でも水の臨界角（約 $0.14^{\circ} ）$ では，その射影は， $3 \mathrm{~cm}$ ほ どにもなり, 試料の均一性が要求される。装置の詳細は, 文献 9）を参照されたい。

\section{4 水面高分子単分子膜および高分子電解質ブラシのナ ノ構造解析}

\section{$4 \cdot 1$ イオン性両親媒性高分子とは}

高分子の世界では，さまざまなブロックポリマーが合 成され，利用されているが，われわれの現在の対象は， イオン性の親水鎖と疎水鎖からなるジブロックコポリ マーである。疎水鎖が短い場合は，水溶性となり，水中 で高分子ミセルを形成するほか，界面不活性性という，

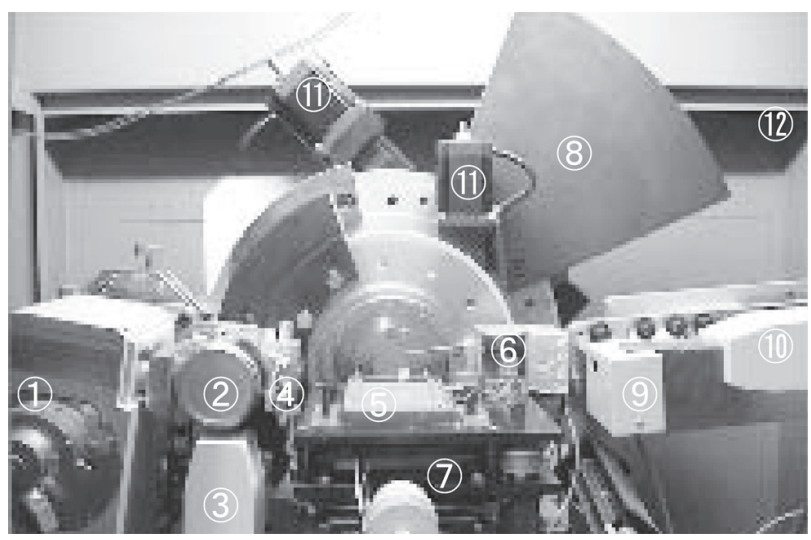

Fig. 4 試料水平型 X 線反射率装置 Rigaku RINT-TTR$\mathrm{MA} A 1$ : 回転対陰極型 X 線発生部 ( $\mathrm{Cu}$ ターゲット), 2: モノクロメータ $(\mathrm{Ge}), 3$ : モニターカウンター 4 : 入射スリット，5:LBトラフ，6:表面圧センサー，7： 試料架台, 8：X線発生部とバランスを取るためのお もり，9：受光スリットおよびアテネーター, 10：シ ンチレーションカウンター, 11：回転モーター, 12 : 防X線カバー (ref.13)。
界面化学の常識を覆す特異な性質を示す ${ }^{17)}$ 。疎水鎖が 十分長い場合は，水に不溶となり，水面上に展開するこ とにより，単分子膜を形成する。われわれの用いている イオン性ジブロックコポリマーを Fig. 5 に示す。両ブ ロックの溶媒への溶解性が大きく異なるため, 合成には 工夫を要した。当初は，イオン基を保護したモノマーを アニオン重合し，脱保護し高分子電解質ブロックとして いたが 18, 19)，その後，二トロキシラジカルを用いたリビ ングラジカル重合を用いるようになり ${ }^{20)}$ ，また最近は， RAFT 重合によりイオン性モノマーを直接ブロック重 合することにより目的ポリマーを得ている ${ }^{21)}$ 。なお, 平滑かつ均一な単分子膜を得るため, 疎水鎖となるブ ロックには，極めて柔軟性の高い，柔らかい高分子を用 いている.高分子の膜というより「油膜」のイメージで ある。

\section{4・2 イオン性両親媒性高分子水面単分子膜}

単分子膜の構造には, Fig. 6 に示す二種類が存在する ことが，われわれのXR，NRによる系統的研究より分 かっている。われわれの興味対象は, 高分子電解質が片 末端を界面（表面）に固定され，「密生」している「高 分子電解質ブラシ」である。高分子電解質ブラシは，極 めて高い摩擦低減性 ${ }^{22)}$ を有するなど, 注目を集めてい るが, われわれの場合は，それを水面上の「疎水層の下」 に形成させたことになる。材料学的には，固体表面に形 成させることになるが，水面単分子膜を利用して高分子 電解質ブラシの研究（とくにナノ構造とその転移）を行

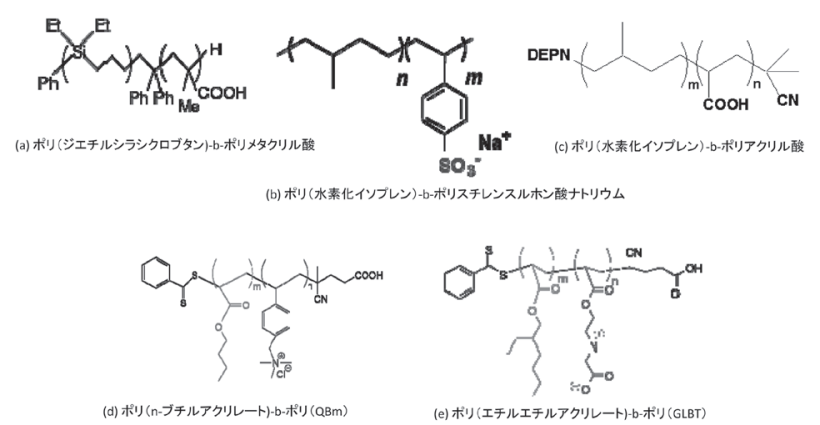

Fig. 5 水面高分子電解質ブラシのナノ構造研究に用いられ たジブロックコポリマー。

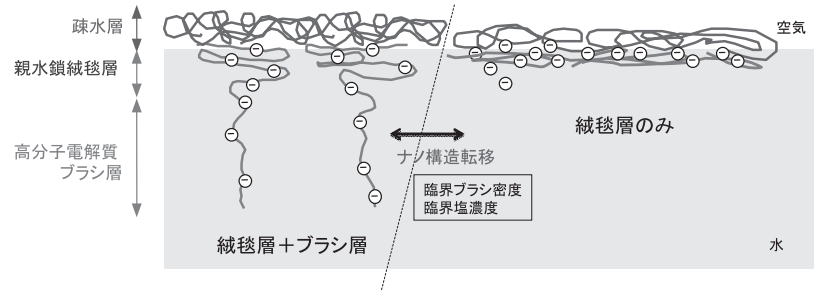

Fig. 6 高分子水面単分子膜における電解質ブラシ層のナノ 構造の模式図。 
うメリットが幾つかある。とくに，LBトラフを用いて， 圧縮，拡張することにより，ブラシ密度（単位面積当た りの高分子電解質の本数）を変化させながら, ブラシの ナノ構造を系統的に調査できる点が大きい。

当初，水面上の疎水層の下には，高分子電解質ブラシ 層が形成されると考え，そのような発表も行っていた ${ }^{23)}$ が，XR デー夕を詳細に再解析すると，高分子水面単分 子膜は, 疎水層とブラシ層の二層構造ではなく, 三層構 造であることが判明した ${ }^{24)}$ 。この第 3 の層は, 疎水層 の直下に形成される親水鎖（イオン性鎖）が密に詰まっ た層で，われわれはこれを絨毯層（carpet layer）と名 付けた。Fig. 7 は，XR プロファイルを二層モデルと三 層モデルでフィットし比較したものである。一見，二層 モデルで十分な一致が見られているように思えるが，拡 大してみると小角部分に明らかな不一致があり，三層モ デルではこれが解消されている。XRは非常に精度の良 い実験法であるので，フィッティングもこの程度の精度 で行わないと，正しい情報を得ることはできない。絨毯 層の存在は予想していなかったが，疎水層が水と直接接 することを避け，界面自由エネルギーを低下させている と考えれば，ごく自然なことと捉えられる。そしてブラ シ密度が低い場合は，イオン性親水鎖はすべて絨毯層形 成に費やされ，ブラシ層は形成されない。ブラシ密度が ある一定值を越えると，䋘毯層の下にブラシ層が形成さ れる。この構造転移を起こすブラシ密度を「臨界ブラシ 密度」と名付けた。

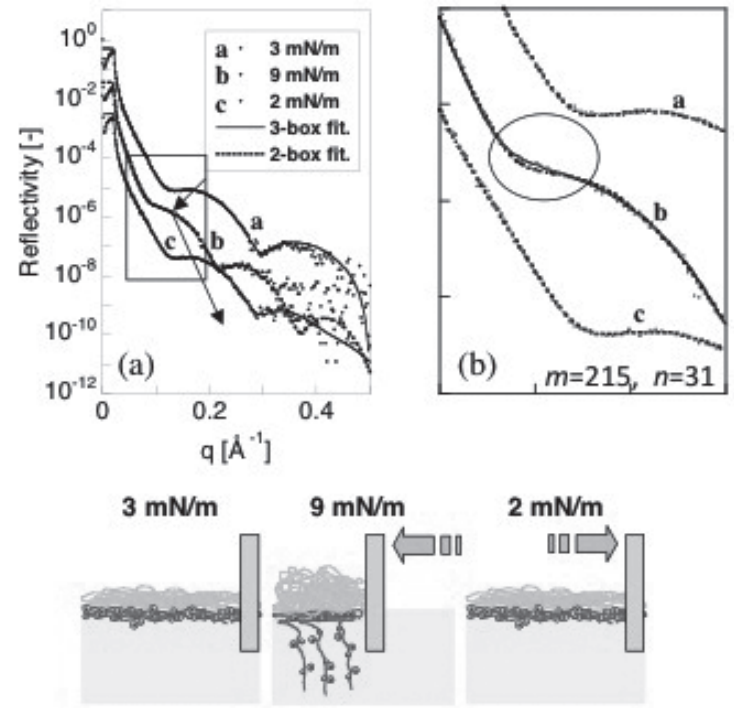

Fig. 7 単分子膜の圧縮・拡張によるXR プロファイルの変 化とナノ構造変化の模式図。条件 a,c では二層モデ ルでフィットできるが, 条件 bでは, 拡大図のよう に再現できず，ブラシ層を含めた三層モデルでよく 一致する。ブラシ形成は可逆的である。ポリマーは 図 5 の b (ref.27b)。

\section{$4 \cdot 3$ 臨界ブラシ密度}

この臨界ブラシ密度が最初に決定されたのは, 弱酸性 のポリメタクリル酸（PMA）ブラシであり, PMA 鎖の 鎖長に依存し， 0.48 本 $/ \mathrm{nm}^{2}$ から 0.2 程度まで低下した $\left(\right.$ Fig. 8 ${ }^{25,26)}$ 。疎水層／水の界面を安定化する為の絨毯 層の厚さには，「これで十分」という最適值があると考 えると, PMA 鎖の鎖長が長くなるにつれ，臨界ブラシ 密度が低下することはごく自然なこととして受け入れら れる。一方, 強酸性のポリスチレンスルホン酸 (PSS) ブラシでは, 臨界ブラシ密度は, 0.12 程度とかなり低い 值となり，またそれはPSSの鎖長に依存しないことが 分かった（Fig. 8)。これは，PMA とPSSで，そのブラ シ形成メカニズムが異なることを意味している。後述の

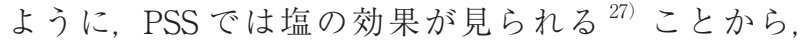
PMA は界面の安定化が主因子であるのに対し，PSS で は, 強酸性の為, イオン間の静電反発が主な要因となっ て，ブラシが形成されるものと考えられる。PAAの臨 界ブラシ密度に明瞭な PAA 鎖長依存性は見られなかっ たが，その值は，0.5 程度と同じ弱酸のPMA と同程度 であった ${ }^{20)}$ 。

\section{$4 \cdot 4$ 強酸性高分子ブラシの臨界塩濃度}

水面の PSS ブラシに対して，塩を添加していくと， 当初, 塩濃度が低い場合は, そのナノ構造には何ら変化 が無く，ある臨界的な濃度を超えると，ブラシが収縮を 始める ${ }^{27)}$ 。この構造変化が起き始める塩濃度が臨界塩

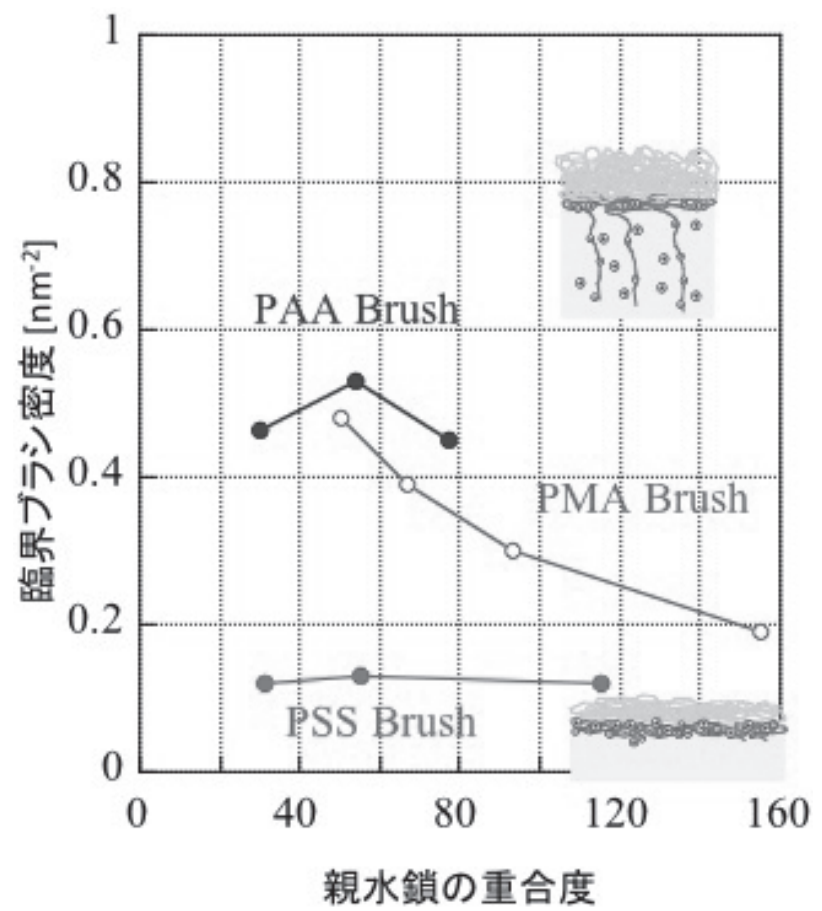

Fig. 8 水面高分子電解質ブラシの臨界ブラシ密度の親水鎖 長依存性（ref.13）。 
濃度である。単分子膜の表面圧もこの值を境に急激に低 下する。このような臨界值が存在するのは, ブラシ内の イオン濃度が極めて高いことに由来する。高分子電解質 ブラシ内は, 高分子イオンが「密生」した状態となって おり, 単純な計算では, ブラシ内の局所的イオン濃度は, $2 \mathrm{M}$ 程度にも達する。したがって，水相に塩を添加して も，その濃度が低い場合は，ブラシ内に塩のイオンは浸 入できず，ブラシ構造はなんら影響を受けない。塩濃度 を増加させていき，ブラシ内外のイオン濃度の大小関係 が逆転すると, 塩イオンはブラシ内に浸入し, ブラシを 伸張させていた静電的斥力を遮蔽するため, ブラシは縮 むとともに表面圧が低下する。Fig. 9 に示す表面圧一定 条件下での XR プロファイルの塩濃度依存性も $[\mathrm{NaCl}]$ $=0.2 \mathrm{M}$ を境に変化していることが分かる。この場合, 臨界塩濃度は $0.2 \mathrm{M}$ ということになる。ブラシ内のイオ ン濃度の計算值は， $2.2 \mathrm{M}$ であるが，このことは，ブラ シ内の $92 \%$ のインが対イオン固定されており, 有効 なイオン濃度は $0.2 \mathrm{M}$ となっていることを意味する。こ の非常に高い対イオン固定度は，ブラシ内がイオン密生 系であることに起因すると考えられる。なお, 塩イオン がブラシ内に浸入した状態で，LBトラフにより単分子 膜を圧縮していくと，ブラシ内外のイオン濃度の再逆転 が起き, ブラシ内の塩イオンがバルクに絞り出される様 子がXRにより確認されている ${ }^{27) 。 ~}$

なお，PSS ブラシでは，この臨界塩濃度にイオン種依 存性が見いだされている。塩アニオンを $\mathrm{Cl}^{-}$とし, カチ オンを $\mathrm{Li}^{+}, \mathrm{Na}^{+}, \mathrm{K}^{+}$と変化させると, 臨界塩濃度は, $\mathrm{Li}^{+}<\mathrm{Na}^{+}<\mathrm{K}^{+}$の順となった。この順はいわゆる Hoffmeister 順列と同等であり，構造形成イオンほど，ブラ シ内に浸入しやすいことを意味している。これはブラシ 内の水の構造と関連していると考えられており,さらに 詳細な検討が進められている ${ }^{28)}$ 。

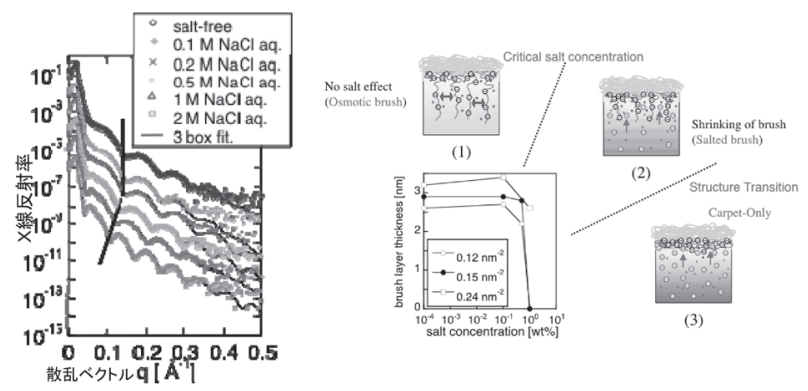

Fig. 9 ポリ水素化イソプレンーポリスチレンスルホン酸ジ ブロックコポリマー水面単分子膜からのX線反射率 曲線の添加塩 $(\mathrm{NaCl})$ 濃度依存性。表面圧 $=30 \mathrm{mN} / \mathrm{m}$, 疎水鎖の重合度: 220 , 親水鎖の重合度:56（ref.27a）。

\section{$4 \cdot 5$ 弱酸性高分子ブラシの塩添加によるナノ構造変 化}

PMA やPAA など弱酸性のブラシの場合は, その塩 濃度依存性は，強酸性とまったく異なる。Fig. 10 には， $\mathrm{PAA}$ ブラシの厚さの塩濃度による変化を絨毯層の厚さ および表面圧とともに示してある。ブラシ層の厚さは, 添加塩濃度の上昇とともに, 一旦増加し, 極大を示した 後, 減少している。表面圧も同様な挙動を示している。 一見，奇妙な挙動に見えるが，添加塩によって影響され る因子が二つあることにより説明できる。一つめは，弱 酸の塩添加による解離の促進である ${ }^{29)}$ 。塩濃度が低い 場合はこれが支配的であり，ブラシ鎖上のイオン数が増 加するために静電的斥力により，ブラシは伸張し，表面 圧は増加する。しかし, さらに塩濃度が増加すると, こ の斥力が塩イオンにより遮蔽され,ブラシは縮み始める。 PMA ブラシに対しても同様な挙動が観察されている ${ }^{30}$ が，このように相反する二つの因子の相乗効果で，極大 という一見奇妙な挙動が現れている。

\section{$4 \cdot 6$ 臨界ブラシ密度の添加塩濃度依存性}

臨界ブラシ密度の塩濃度依存性（Fig. 11）からもブ ラシ形成機構に関する興味ある知見を見て取れる。強酸 性の PSS ブラシの臨界ブラシ密度には，臨界塩濃度と 同様な挙動が見られ, ある塩濃度を超えたところで, 臨 界ブラシ密度の上昇が観察される。ブラシ形成機構に静 電的な機構が関与していることが明らかである。一方, 弱酸のPAA ブラシに対しては, その臨界ブラシ密度は, 塩濃度依存性を示していない。 $0.5 / \mathrm{nm}^{2}$ 程度で一定であ る。したがって, 静電的な効果は重要因子ではなく, 鎖 長依存性も明確でなかったこと, 絨毯層の厚さが, PSS や PMA より厚く $(3 \mathrm{~nm})$ 水を含んでいること ${ }^{20)}$ など
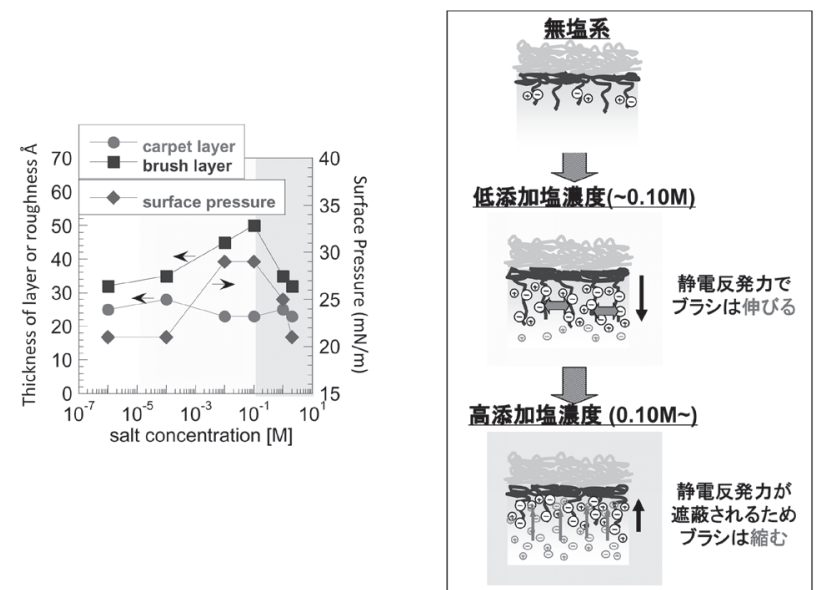

Fig. 10 弱酸性水面高分子ブラシの添加塩によるナノ構造変 化。ポリマー：水素化ポリイソプレン（重合度 76） -b- ポリアクリル酸（重合度 $77 ）$ ブラシ密度 $\fallingdotseq 0.50$ $\mathrm{nm}^{-2}$ (ref.20)。 


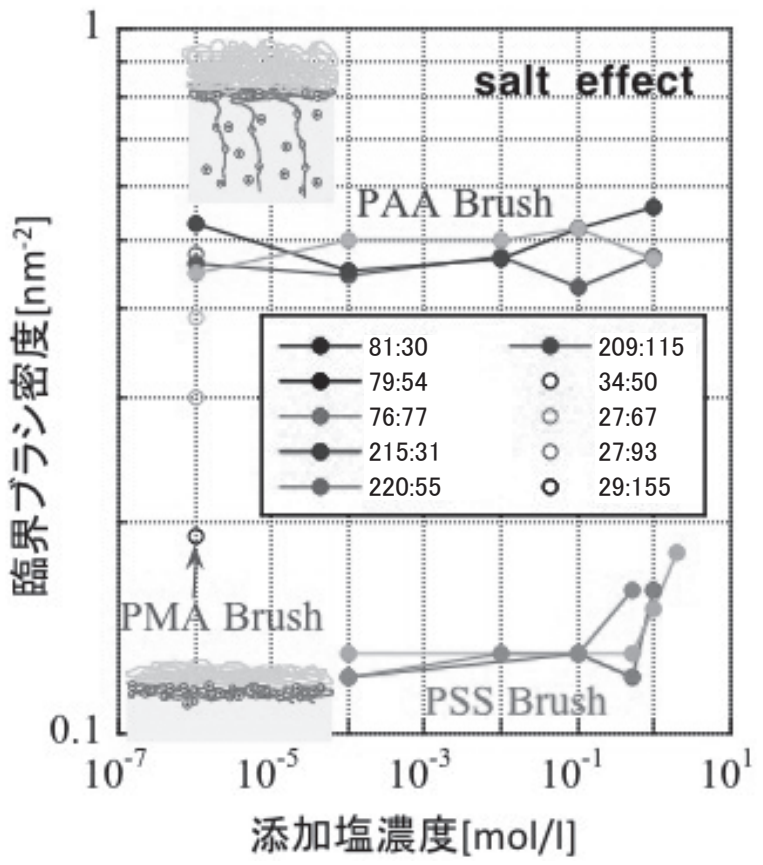

Fig. 11 各高分子電解質ブラシの臨界ブラシ密度の添加塩濃 度依存性 (図中の数字は, ブロック鎖の重合度 $\mathrm{m}$ (疎 水鎖 $): \mathrm{n}$ (親水鎖 $))($ ref.13)。

と併せて考えると，立体的な効果など，PSSおよび PMA とは異なる機構でブラシが形成されていると考え るのが妥当と思われる。

\section{5 将来性}

以上のように，同じアニオン性高分子ブラシであって も, 強酸性の PSS ブラシと弱酸性の PMA およびPAA ブラシでは，その形成メカニズムが異なることが示唆さ れた。また, PMA とPAAでも，その挙動は同じでは なく，より分厚い絨毯層の形成や添加塩の影響を受けな いことなどから，PAA では，必ずしも，PMAのよう な「界面の安定化」が第 1 要因とはなっていないと考え られる。また，最近では，カチオン性高分子ブラシにお いても絨毯層の形成と「絨毯層のみ」/「絨毯層+ブラシ 層」の転移が観察されている ${ }^{21)}$ 。さらには, 両イオン 性のベタインブラシについても研究が進んでおり，これ ら高分子電解質ブラシの構造およびその形成メカニズム について，普遍性とそれぞれの特異性が明らかになりつ つある。このような包括的検討が可能となったのは，水 面単分子膜中のブラシ構造をモデル系として, とくにブ ラシ密度を自由に変化させながら，in situにて，XRで 直接観察できたことが大きな要因であることは言うまで もない。

放射光 X 線を光源とする XR 装置も Spring-8 などで 開発が進められている。その高強度を活かして, 時分割
測定もすでに分単位では可能となっている ${ }^{31)}$ 。さらには, $\mu$ ビーム化により，「面内スキャン」も可能と考えられ， ドメイン構造を有する単分子膜のナノ構造解析がさらに 発展すると期待される。液 / 液界面の測定 ${ }^{8)}$ や単粒子 膜への応用例 $\left.{ }^{22}\right)$ もりり，NR と併せ，さまざまなソフ 卜界面のナノ構造解析に必須の構造解析手段として活用 されていくものと期待される。

\section{文 献}

1) H. Kiessig, Ann. Phys., 10, 769 (1931).

2) Jens Als-Nielsen, Elements of Modern X-ray Physics, Wiley (2001).

3) J. Daillant \& A. Gibaud, X-Ray and Neutron Reflectivity: Principles and Applications, Springer (1999).

4) Metin Tolan, X-Ray Scattering from Soft-Matter Thin Films: Materials Science and Basic Research, Springer (1999).

5）桜井健次 編， X 線反射率法入門，講談社（2009）.

6) A. Braslau, M. Deutsch, P. S. Pershan, A. H. Weiss, J. Als-Nielsen \& J. Bohr, Phys. Rev. Lett., 54, 114 (1985).

7) M. L. Schlossman, D. Synal, Y. Guan, M. Meron, G. Shea-McCarthy, Z. Huang, A. Acero, S. M. williams, S. A. Rice \& P. J. Viccaro, Rev. Sci. Instrum., 68, 4372 (1997).

8) S. V. Pingali, T. Takiue, G. Luo, A. M. Tikhonov, N. Ikeda, M. Aratono \& M. L. Schlossman, J. Phys. Chem. B, 109 (3), 1210-25 (2005).

9）松岡秀樹, 籠恵太郎, 山岡仁史, 理学電機ジャーナル, 30 (2), 14-23 (1999).

10) H. Yamaoka, H. Matsuoka, K. Kago, H. Endo, J. Eckelt \& R. Yoshitome, Chem. Phys. Lett., 295, 245-8 (1998).

11）毛利恵美子，松本幸三，松岡秀樹，高分子，53（7）, 486-9 (2004).

12）松岡秀樹，松本幸三，毛利恵美子，P. Kaewsaiha，高 分子論文集，62（10），449-57（2005）.

13）松岡秀樹, 水面高分子電解質ブラシ, カレントレビュー 04 新しい局面を迎えた界面の分子科学, 日本化学会編

14） L. G. Parratt, Phys. Rev., 95, 359 (1954)

15) http://www.nims.go.jp/xray/lab/murex-x-ray-reflectivity-software.html

16) http://www.hmi.de/bensc/download/parratt32/ parratt32_setup.exe

17) A. Ghosh, S. Yusa, H. Matsuoka \& Y. Saruwatari, Langmuir, 27, 9237-44 (2011).

18) E. Mouri, K. Matsumoto, H. Matsuoka \& N. Torikai, Langmuir, 21 (5), 1840-7 (2005).

19) P. Kaewsaiha, K. Matsumoto \& H. Matsuoka, Langmuir, 20 (16), 6754 -61 (2004).

20) H. Matsuoka, Y. Suetomi, P. Kaewsaiha \& K. Matsumoto, Langmuir, 25 (24), 13752-62, (2009).

21) S. Fujita, S. Nakayama, A. Ghosh, S. Yusa, Y. Saruwatari \& H. Matsuoka, Polym. Prep. Jpn., 59, 4445 (2010).

22) U. Raviv, S. Giasson, N. Kampf, J. F. Gohy, R. erome, \& 
J. Klein, Nature (London), 425, 163 (2003).

23) E. Mouri, K. Matsumoto. H. Matsuoka \& H. Yamaoka, Langmuir, 18 (10), 3865-74 (2002).

24) E. Mouri, K. Matsumoto \& H. Matsuoka, J. Polym. Sci., B, 41 (16), 1921-8 (2003).

25) H. Matsuoka, Y. Furuya, P. Kaewsaiha, E. Mouri \& K. Matsumoto, Langmuir, 21 (15), 6842-5 (2005).

26) H. Matsuoka, Y. Furuya, P. Kaewsaiha, E. Mouri \& K. Matsumoto, Macromolecules, 40, 766-9 (2007).

27) a) P. Kaewsaiha, K. Matsumoto \& H. Matsuoka, Langmuir, 23 (13); 7065-71 (2007). b) Langmuir, 23 (1), 20-4 (2007).
28) S. Nakayama, T. Yamada, P. Kaewsaiha \& H. Matsuoka, Polym. Prep. Jpn, 58, 3498 (2009).

29) G. W. Castellan, Physical Chemistry, $3^{\text {rd }}$ ed., Chapter 16, Addison-Wesley (1983).

30) E. Mouri, P. Kaewsaiha, K. Matsumoto, H. Matsuoka \& N. Torikai, Langmuir, 20 (24), 10604-11, (2004).

31) Y. F. Yano, T. Uruga, H. Tanida, H. Toyokawa, Y. Terada, M. Takagaki \& H. Yamada, Eur. Phys. J. Special Topics, 167, 101-5 (2009).

32) E. Mouri, Y. Okazaki, K. Yoshinaga \& H. Matsuoka, J. Nanosci. Nanotechnol., 9 (1), 327-33 (2009). 